\section{Research Aвticle: Biology and predatory behaviour of an assassin bug, Sycanus collaris (Fabricius) on rice meal moth, Corcyra cephalonica (Stainton) and leaf armyworm, Spodoptera litura (Fabricius)}

\author{
S. JESU RAJAN, N. SUNEETHA AND R. SATHISH
}

Article Chronicle :

Received :

15.07.2017;

Accepted :

30.07.2017

\section{KeY Words:}

Assassin bug,

Sycanuscollaris

(Fabricius), Biology,

Predation, Rice meal

moth, Corcyra

cephalonica

(Stainton), Leaf

armyworm,

Spodoptera litura $(\mathrm{F}$.

of

SUMMARY : The effective utilization of any biological control agent relies upon its comprehensive knowledge on bioecology, ecophysiology and behaviour. Hence, in the present study, the biology and predatory behaviour of third, fourth and fifth nymphal instars and adults of an assassin bug, Sycanuscollaris (Fabricius) to the larvae of rice meal moth, Corcyra cephalonica (Stainton) and leaf armyworm, Spodoptera litura (F.) was observed in the laboratory. The eggs were laid in clusters and cemented to each other and the surface of the plastic cylinder. The egg hatched after 11 to 15 days with each cluster having 15 to 70 eggs. Five nymphal instar stages were recorded. The mean longevity of each nymphal stage was $11.38 \pm 0.55,12.24 \pm 1.87,12.58 \pm 1.24,14.62 \pm 1.67,15.42 \pm 1.14$ days when fed with C. cephalonica and $12.54 \pm 0.57,12.24 \pm 1.12,13.26 \pm 1.16,14.42 \pm 0.86,16.58 \pm 1.70$ days when fed with $S$. litura. The mean longevity of male and female adult fed with C. cephalonica was $73.58 \pm 2.12$ and $80.64 \pm 3.40$ days, respectively. The mean longevity of male and female adult fed with $S$. litura was $75.82 \pm 2.82$ and $85.48 \pm 3.20$ days, respectively. The sequential acts of predatory behaviour and the time taken for each predatory act such as arousal, approach, capturing, paralysing, sucking and postpredatory behaviour and the number of piercing and sucking sites were observed. The predator took less time to predate upon the larvae of S. litura than that of C. cephalonica.

How to cite this article : Rajan, S. Jesu, Suneetha, N. and Sathish, R. (2017). Biology and predatory behaviour of an assassin bug, Sycanus collaris (Fabricius) on rice meal moth, Corcyra cephalonica (Stainton) and leaf armyworm, Spodoptera litura (Fabricius). Agric. Update, 12(TECHSEAR-5) : 1181-1186; DOI: 10.15740/ HAS/AU/12.TECHSEAR(5)2017/1181-1186.
Author for correspondence :

\section{S. JESU RAJAN}

National Institute of

Plant Health

Management (NIPHM),

Rajendranagar,

HYDERABAD

(TELANGANA) INDIA

See end of the article for

authors' affiliations 